\title{
Export-led Growth in Bangladesh: A Time Series Analysis
}

\author{
Khawaja Abdullah Al Mamun*
}

Hiranya K Nath ${ }^{\dagger, \ddagger}$

\begin{abstract}
This paper examines time series evidence to investigate the link between exports and economic growth in Bangladesh. Using quarterly data for a period from 1976 to 2003 the paper finds that industrial production and exports are cointegrated. The results of an Error Correction Model (ECM) suggest that there is a long-run unidirectional causality from exports to growth in Bangladesh.
\end{abstract}

Keywords: Export-led growth; Cointegration; Granger causality; Error-correction model

JEL Classification: O1; F1

* Department of Economics, Southern Methodist University, Dallas, TX 75275-0496; Phone: 214-7683637; E-mail: akhawaja@mail.smu.edu.

† Department of Economics and International Business, Sam Houston State University, Huntsville, TX 77341-2118; Phone: 936-294-4760; Fax: 936-294-3488; E-mail: eco_hkn@shsu.edu.

‡ Corresponding author 


\section{INTRODUCTION}

In over three decades of its existence, Bangladesh has witnessed substantial growth in its exports of goods and services ${ }^{1}$. Over this period economic growth has accelerated with GDP initially recording an average growth rate of below 3 percent in early seventies and about 5 percent during the nineties ${ }^{2}$. The trade and industrial policy regimes have changed from being highly import substituting and government controlled to being more liberalized and deregulated. In the seventies, Bangladesh was a strongly inward-oriented economy ranking among the top in price distortions caused by high tariff barriers ${ }^{3}$. By the eighties, the dismal growth performance of the early 70s and a general euphoria about export-led growth - reinforced by disillusionment of most developing countries over import- substituting development strategies they experimented with during the fifties through the seventies on one hand, and by the success of the Asian Tigers with exportoriented development strategies on the other - made a case for policy shift in Bangladesh as in many other developing countries ${ }^{4}$.

Progressive trade liberalization and domestic deregulation were the focuses of trade and industrial policies since the eighties which recognized the need for greater efficiency and international competitiveness, faster growth of export-oriented industries, reduction of regulation and control along with tariff rationalization, a liberalized marketbased competitive structure, and disinvestment of public sector enterprises. To promote

\footnotetext{
${ }^{1}$ The total value of exports increased from \$468.8 million (2000 constant USD) in 1976 to 6951 million in 2002 according to International Monetary Fund (IMF).

${ }^{2}$ See Ahmed and Sattar (2004) for a detailed account.

${ }^{3}$ According to Dodaro (1991), Bangladesh recorded the second highest value of the price distortion index only after Ghana - in a group of 41 countries.

${ }^{4}$ See Love (1995) for a discussion
} 
exports, several measures were undertaken. For example, in the eighties the government established the first export processing zone in Chittagong. It was followed by other measures such as tax holidays to the export-oriented enterprises and income tax rebates. Later on, two more export processing zones were established in Dhaka and Khulna. In recent years, Bangladesh has experienced not only substantial increase in the volume of exports but also important changes in the composition of exports away from traditional items such as jute and jute products, and towards new manufactured products such as ready-made garments.

There has been a substantial empirical literature on the effects of exports on growth. Among the early studies, Michaely (1977), Balassa (1978), Chow (1987), Darrat (1987) have provided evidence in support of export-led growth hypothesis for various developing countries. In recent times, Abual-Foul (2004) and Awokuse (2004) have established unidirectional causality from exports to output for Jordan and Canada respectively. New developments in time series analysis have facilitated more sophisticated examination of the time series evidence on causal links between exports and growth. To the best of our knowledge, no study has ever done a time series analysis of the export-output relationship for Bangladesh. Using time series techniques, the current research shows that there is evidence of a long-run equilibrium relationship between exports and output in Bangladesh.

The rest of the paper is organized as follows. In section II, we discuss data, methodology and empirical results. Section III summarizes and concludes our discussion. 


\section{DATA, METHODOLOGY AND EMPIRICAL RESULTS}

We obtain quarterly data on industrial production index ${ }^{5}$, exports of goods and services and exports of goods only for a period from 1976: I to 2003: III, from the International Financial Statistics published by the International Monetary Funds. For all three data series the base year is 2000 and the export values are in U.S. constant dollars. Let $y$ and $x$ denote the logarithms of industrial production index and exports respectively. Note that 'exports of goods and services' and 'exports of goods only' ${ }^{6}$ will be used as two alternative measures of exports.

\section{Unit Root Test}

We conduct Augmented Dickey-Fuller (ADF) tests to find out the order of integration for each of the three series. First, we conduct the test in levels and then in first differences. For each series we start with the most flexible specification of the test equation that includes an intercept and a trend:

$$
\Delta z_{i, t}=\alpha_{i, o}+\alpha_{i, 1} t+\gamma z_{i, t-1}+\sum_{j=1}^{p} \beta_{i, j} \Delta z_{i, t-j}+\varepsilon_{i, t}
$$

where $z_{i}$ is the variable of interest where $i=1,2$ indexes the variable (i. e. $z_{1}=y$ and $z_{2}=$ $x$ ), $\alpha_{i, 0}$ represents the intercept term, $t$ is the time trend, $\Delta z_{i}$ s are the augmented terms, $p$ is the appropriate lag length of the augmented terms and $\varepsilon_{i}$ is the white noise error term. The ADF test is essentially the test of significance of the coefficient $\gamma$ in the above

\footnotetext{
${ }^{5}$ Since GDP data are not available at quarterly frequency we use industrial production index.

${ }^{6}$ Since we are using industrial production index it seems more appropriate to use 'exports of goods only' but 'exports of services' may indirectly affect industrial production. Both series, however, display similar patterns over the sample period.
} 
equation. In order to select the lag length $p$, we start with a maximum lag of 8 and pare it down to the appropriate lag by examining the Akaike Information Criterion (AIC) ${ }^{7}$. If we do not find the intercept and the trend - both or one of them - to be statistically significant at $10 \%$ significance level, we drop the insignificant term(s) and re-estimate the test statistics. The results are reported in Table 1 . The number of lags of the augmented terms and other specifications of the test equation are included in the table. As we can see, all three series are integrated of order one, i.e. I (1).

\section{Engle-Granger Cointegration Test}

Given that both $y$ and $x$ are I (1) we can use Engle-Granger cointegration test procedure to examine if industrial production and exports are cointegrated. This procedure involves testing the residuals for stationarity (using Dickey-Fuller (DF) test method), obtained from an OLS regression of industrial production on contemporaneous values of exports:

$$
y_{t}=\beta_{0}+\beta_{1} x_{t}+e_{t}
$$

Note that equation (2) represents a long-run equilibrium relationship between industrial production and exports. The estimated equations for two alternative measures of exports and DF test statistics for the residuals are reported in Panel A and Panel B respectively of Table 2. We conduct two versions of the DF test: one with no lag and the other with 5 lags (that is, we include augmented terms). These tests however give contradictory

\footnotetext{
${ }^{7}$ There is no general rule as to how one chooses the maximum lag length to start with. Enders (1995) suggests that one should 'start with a relatively long lag length...' (pp.227). Some researchers use the following rule of thumb: start with a maximum lag length equal to the cube root of the number of observation which is $4.8(\cong \sqrt[3]{111})$ in our case. We also use other information criteria such as Schwarz Criterion (SC) or Hannan-Quinn Criterion (HQC). Most times these criteria choose the same lag length. Even for cases with different lag lengths selected by different criteria the ADF test results are qualitatively similar.
} 
results: while the test with no lag indicates that the residuals are stationary, the test with 5 lags (selected using AIC) indicates that they are $\operatorname{not}^{8}$. Note that since the residuals are generated from a regression equation the standard Dickey-Fuller table cannot be used. We use the critical values provided by Engle and Granger (1987) and include them in Table 2. The estimated cointegrating equation indicates that there is a significant positive long-run relationship between exports (no matter whichever measure we use) and industrial production in Bangladesh.

\section{Error-Correction Model and Granger Causality}

The existence of a cointegrating relationship suggests that we estimate an error-correction model (ECM) of industrial production and exports, as represented by the following equation:

$$
\Delta z_{i, t}=\delta_{i, o}+\delta_{i, 1} \hat{e}_{t-1}+\sum_{i=1}^{2} \sum_{j=1}^{p} \lambda_{i, j} \Delta z_{i, t-j}+\xi_{i, t}
$$

Enders (1995) describes this equation as a near VAR. The term $\hat{e}_{t-1} \mathrm{~s}$ are obtained from the estimated cointegrating equations presented in Table 2, and the coefficient $\delta_{i, 1}$ represents the speed of adjustment after the growth rate of industrial production (or the growth rate of exports) deviates from the long-run equilibrium in period $t$ - 1 . In other words, it represents the long-run causal effect in relation to the long-run equilibrium relationship of the cointegrated processes. The coefficients of the lagged values, $\lambda_{2, j}$, in the first of the two equations represent short-run effects of exports on industrial

\footnotetext{
${ }^{8}$ Because of the low power of ADF tests, some studies (e.g. Freeman 2001) suggest that one should experiment with the lag structure to determine if cointegrating relationship can be found between variables 'close' in time. The stationarity tests of the residuals obtained from experiments with various lags suggest that there is a cointegrating relationship between $y$ and 8th lag of $x$.
} 
production and $\lambda_{1, j} \mathrm{~s}$ in the second equation represent short-run effects of industrial production on exports. A test of joint significance of these lagged terms constitutes a short-run Granger causality test.

The results are reported in Table 3. The estimated value of the speed of adjustment coefficient is negative and statistically significant in the industrial production equation as we can see from both the t-statistics and the F-statistics for each case in Panel $\mathrm{A}$ and $\mathrm{B}^{9}$. It indicates that the further away industrial production deviates from its longrun relationship with exports, the lower is the growth rate and vice versa. The speed of adjustment coefficient in the export equation is statistically significant in none of the two cases. The short-run Granger causality test results reported in the last row of each panel in Table 3 indicate that there is no causal relationship between export growth and industrial growth.

\section{III.CONCLUDING REMARKS}

In this paper we examine time series evidence of export-led growth in Bangladesh. While our analysis suggests that there is a positive long-run equilibrium relationship between exports and industrial production, there is no evidence of short-run causal relationship between these two variables. Furthermore, the long-run causality seems to run from exports to industrial production.

\footnotetext{
${ }^{9}$ However, the result is stronger when we use 'exports of goods only'.
} 
Table 1: Augmented Dickey-Fuller Test Results

\begin{tabular}{|c|c|c|c|}
\hline & $\begin{array}{c}\text { Industrial } \\
\text { production } \\
(y)\end{array}$ & $\begin{array}{c}\text { Exports of } \\
\text { goods and } \\
\text { services }(x)\end{array}$ & $\begin{array}{c}\text { Exports of } \\
\text { goods only } \\
(x) \\
\end{array}$ \\
\hline \multicolumn{4}{|l|}{ Panel A: In levels } \\
\hline Is an intercept term included in the test equation? & yes & yes & yes \\
\hline Is a time trend included in the test equation? & yes & yes & yes \\
\hline Lag length of the augmented terms & 4 & 4 & 5 \\
\hline ADF test statistics & -1.98 & -1.94 & -2.05 \\
\hline MacKinnon’s p-value & 0.60 & 0.62 & 0.57 \\
\hline \multicolumn{4}{|l|}{ Panel B: In differences } \\
\hline Is an intercept term included in the test equation? & yes & yes & yes \\
\hline Is a time trend included in the test equation? & no & no & no \\
\hline Lag length of the augmented terms & 3 & 3 & 2 \\
\hline ADF test statistics & -5.93 & -5.98 & -10.65 \\
\hline MacKinnon’s p-value & 0.00 & 0.00 & 0.00 \\
\hline
\end{tabular}


Table 2: Engle-Granger Cointegration Test Results

\section{Panel A: Exports of goods and services}

Estimated long-run equilibrium relationship: (cointegrating equation)

$$
y_{t}=1.34+0.43 x_{t}+e_{t}
$$

(15.68) (31.66)

\begin{tabular}{lcc}
\hline Dickey-Fuller Test on $\left\{\hat{e}_{t}\right\}$ & & \\
\hline & Lag $=0$ & Lag $=5$ \\
\cline { 2 - 3 } Test Statistic & -5.96 & -1.93 \\
5 percent critical value & -3.37 & -3.17 \\
\hline
\end{tabular}

\section{Panel B: Exports of goods only}

Estimated long-run equilibrium relationship: (cointegrating equation)

$$
y_{t}=1.48+0.42 x_{t}+e_{t}
$$

(19.60) (33.99)

\begin{tabular}{lcc}
\hline Dickey-Fuller Test on $\left\{\hat{e}_{t}\right\}$ & & \\
\hline & Lag $=0$ & Lag $=5$ \\
\cline { 2 - 3 } Test Statistic & -6.77 & -1.99 \\
5 percent critical value & -3.37 & -3.17 \\
\hline
\end{tabular}

Note: The t-statistics for estimated coefficients in the cointegrating equations are shown in parentheses below the equations. The 5 percent critical values are from Engle and Granger (1987) as reported in Enders (1995), pp.383. 
Table 3: Error-Correction Model and Granger Causality Test

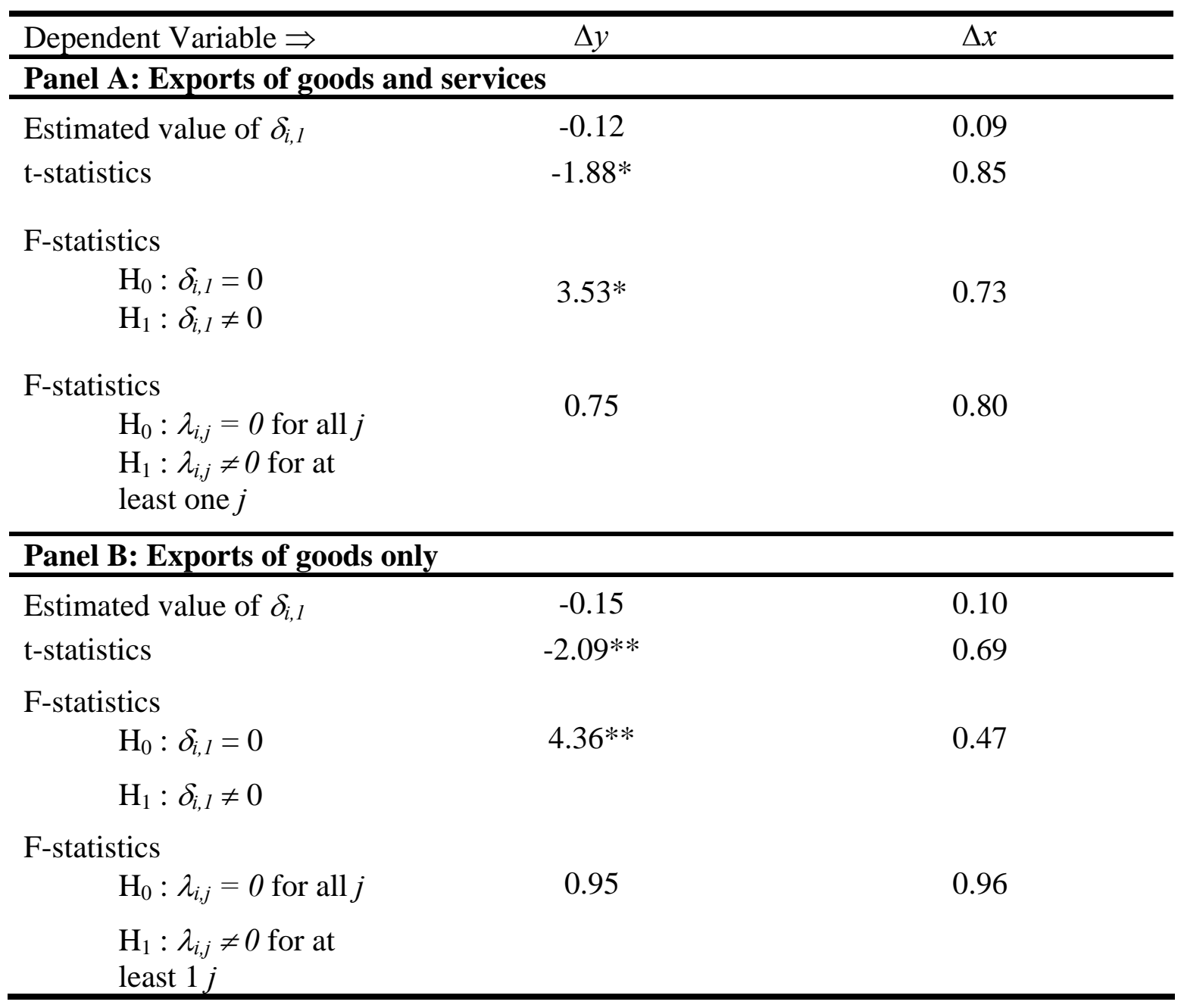

Note: * indicates significance at 10 percent level and $* *$ indicates significance at 5 percent level. 


\section{REFERENCES}

Abual-Foul, Bassam (2004) Testing the export-led growth hypothesis: evidence from Jordan, Applied Economics Letters, 11, pp. 393-396

Awokuse, Titus O. (2004) Is the export-led growth hypothesis valid for Canada? Canadian Journal of Economics, 36, pp. 126 - 136

Ahmad, Sadiq and Zaidi Sattar (2004) Trade Liberalization, Growth and Poverty Reduction: The Case of Bangladesh, Washington, D.C.: World Bank.

Balassa, Bela (1978) Exports and Economic Growth: Further Evidence, Journal of Development Economics, 5, pp. 181-189.

Chow, Peter C. Y. (1987) Causality between Export Growth and Industrial development: Empirical Evidence from NICs, Journal of Development Economics, 26, pp.5563.

Darrat, A.F. (1987) Are exports an engine of growth? Another look at the evidence, Applied Economics, 19, pp.277-8

Dodaro, S (1991) Comparartive Advantage, Trade and Growth: Export-led Growth Revisited, World Development, 19, pp. 1153-65

Enders, Walter (1995) Applied Econometric Time Series, New York: John Wiley \& Sons, Inc.

Engle, Robert E and Clive W. Granger (1987) Cointegration and Error-Correction: Representation, Estimation, and Testing, Econometrica, 55, pp. 251-76

Freeman, Donald G (2001) Beer and business cycle, Applied Economics Letters, 8, 51-54

International Monetary Funds: International Financial Statistics, (http://ifs.apdi.net/imf/logon.aspx) Washington D.C.: IMF

Love, James (1995) Adoption of the Export-led Growth Strategy in Bangladesh: Some Thoughts. In Grieve, Roy H.; Huq, M. Mozammel, eds. Bangladesh: Strategies for Development, Dhaka: University Press.

Michaely, Michael (1977) Exports and Growth: An Empirical Investigation, Journal of Development Economics, 4, pp. 49-53. 